(C) 1988 ISIJ

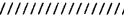

論 文

|IIIIIIIIIIIIII!

\section{ホットストリップミルにおける \\ 板プロフィル・平坦度制御}

\title{
Profile and Shape Control in Hot Strip Mill
}

\section{Ryoichi Takahashi, Tsuyoshi Nunokawa and Ei Takeda}

Synopsis :

A new profile and shape control system has been developed for use in hot strip mills at Wakayama Steel Works and Kashima Steel Works.

The control system consists of variable crown (VC) rolls, work roll benders and work roll shifting devices on the last three stands of the finishing train. These devices can be preset so that the desired strip profile can be obtained. To achieve this, new mathematical models were developed which could be used to calculate the thermal roll crown, the roll wear, the $\mathrm{VC}$ roll profile and the strip profile. These models are considered to be suitable for use in online calculations.

Key words : rolling; computer control ; modelling; process control; hot strip mill ; profile ; shape ; flatness ; strip crown.

\section{1. 緒}

言

ホットストリップミルのスケジェールフリー圧延を実 施するためには，ロールカーブを統一し，ロールの熱澎 張や摩耗が進んでも常に狙いの板プロフィルが実現でき る板プロフィル制御が重要な要素技術である．住友金属 工.業和歌山製鉄所・鹿島製鉄所では仕上圧延機後段ス夕 ンドの VC (Variable Crown) ロール・強力ワークロー ルベンダー・ワークロールシフトを制御手段とした板プ ロフィル・平坦度制御システムを開発実用化した。

本報告では, 制御システムの数式モデルと実機での適 用効果について述べる.

\section{2. 板プロフィル・平坦度制御装置の概要}

鹿島製鉄所における板プロフィル・平坦度制御装置の 概要は次のとおり（Fig. 1, Table 1)（和歌山製鉄所も ほほ同様)。

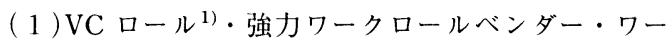
クロールシフトを仕上压延機後段 3 スタンドに設置

(2) X 線走査型板プロフィル計・光学式平坦度計を仕

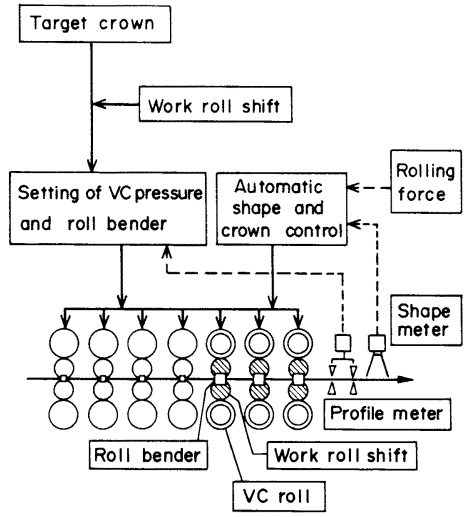

Fig. 1. Profile and shape control system.

Table 1. Specifications of crown control device.

\begin{tabular}{l|cccc|ccc}
\hline \multicolumn{1}{c|}{ Stand } & $\mathrm{F}_{1}$ & $\mathrm{~F}_{2}$ & $\mathrm{~F}_{3}$ & $\mathrm{~F}_{4}$ & $\mathrm{~F}_{5}$ & $\mathrm{~F}_{6}$ & $\mathrm{~F}_{7}$ \\
\hline $\begin{array}{l}\text { Work roll shift (Stroke) } \\
\text { VC roll (Variable crown range) }\end{array}$ & - & - & - & - & $400 \mathrm{~mm}$ \\
\hline Work roll bender & \multicolumn{2}{|c|}{$76 \mathrm{t} / \mathrm{chock}$} & $170 \mathrm{t} / \mathrm{chock}$ \\
\hline
\end{tabular}

昭和 61 年 10 月本会講演大会にて発表 昭和 62 年 10 月 22 日受付 (Received Oct. 22, 1987)

* 住友金属工業(株)システムエンジニアリング本部（System Engineering Division, Sumitomo Metal Industries, Ltd., 1-3 Nishinagasuhondori Amagasaki 660)

*2 住友金属工業(株)鹿島製鉄所 (Kashima Steel Works, Sumitomo Metal Industries, Ltd.)

*3 住友金属工業(株)和歌山製鉄所（Wakayama Steel Works, Sumitomo Metal Industries, Ltd.) 
上圧延機出口に設置

(3)板プロフィル・平坦度制御のためのプロセスコン ピューターを増設

ここで,平坦度計は住友金属工業独自開発のもので,測定 原理はつぎのとおりである。すなわち, $\operatorname{Ar}($ アルゴン) イ オンレーザー光束を 3 分割し, 振動ミラーで斜め上方よ り鋼板上に走査照射する．この鋼板上の光束像を高速走 査型テレビカメラで撮影することにより鋼板の高さ方向 変位を測定し, 平坦度を演算するものである ${ }^{2)}$ (Fig. 2).

\section{3. 板プロフィル制御}

仕上压延機の設定計算モデルのフローチャートを Fig. 3 に示す. 压延荷重を推定してロールギャップと ロール周速度を決定する以外に, 所望の板プロフィルを 実現させるためには，ロールプロフィルを推定すること によりロールシフト量を決定し, 板プロフィルを精度良 く予測することによりVCロール圧力・ロールベンド 力を設定することが必要となる.

\section{$3 \cdot 1$ ロールプロフィル計算モデル}

ロールのプロフィルについてはイニシャルロールカー

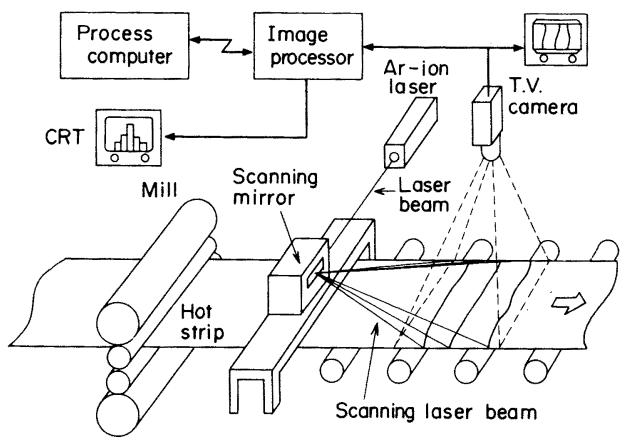

Fig. 2. Schematic drawing of shape meter.

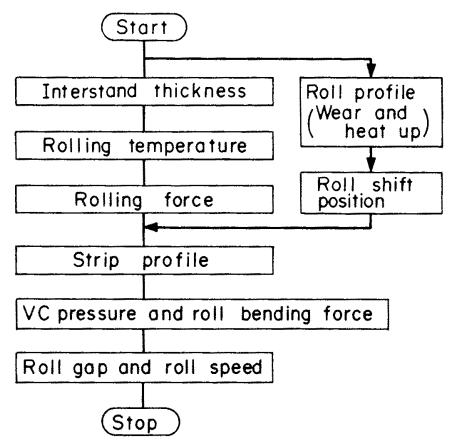

Fig. 3. Flow diagram of setup model.
ブの他に, ワークロールのサーマルクラウンと摩耗及び VCロールのふくらみについて考慮した。

$3 \cdot 1 \cdot 1 \quad$ ワークロールのサーマルクラウン ${ }^{3)}$

圧延材からの入熱によりワークロールは熱膨張する. この現象を軸対称の 2 次元(ロール胴長方向と半径方向) 熱伝導方程式にて表し，これを差分法にて解く.

$$
c \rho \frac{\partial \theta}{\partial t}=\frac{1}{r} \frac{\partial}{\partial r}\left(\lambda r \frac{\partial \theta}{\partial r}\right)+\frac{\partial}{\partial z}\left(\lambda \frac{\partial \theta}{\partial z}\right)
$$

境界条件

$$
\begin{aligned}
& \text { ロール表面において } \\
& -\lambda \frac{\partial \theta}{\partial r}=h_{w}\left(\theta-\theta_{0}\right)-q_{s} \cdot \delta(z) \\
& \text { ロール端部において } \\
& -\lambda \frac{\partial \theta}{\partial z}=h_{z}\left(\theta-\theta_{0}\right)
\end{aligned}
$$

ここで, $\theta$ はロール温度, $t$ は時間, $r$ は半径方向唑標, $z$ は胴長方向座標, $c$ は比熱, $\rho$ は密度, $\lambda$ は熱伝導率, $\theta_{0}$ は䨌囲気温度, $h_{w}, h_{z}$ は熱伝達率である， $q_{s}$ は压延 材からの熱流束であり，圧延材とロールとの接触を半無 限体の接触と考えて求める. $\delta(z)$ は压延材との接触部 で 1 , 非接触部で 0 となる関数である（1)式にて求 めたロール温度をもとにロールのサーマルクラウン $C_{H}(z)$ を( 4$)$ 式にて求める.

$$
C_{H}(z)=\frac{4}{R}(1+v) \alpha \int_{0}^{R}\left(\theta-\theta_{0}\right) r d r
$$

ここで, $v$ はポアソン比， $\alpha$ は線膨張率， $R$ はロール 半径である.

$3 \cdot 1 \cdot 2$ ワークロールの摩耗クラウン

ロールの摩耗は単位幅当たりの圧延荷重と压延材との 接触回数に依存するとして，摩耗プロフィル $C_{W}(z)$ を (5)式にて表し，係数 $A_{W}$ をロール摩耗の実測デー夕 により求めた。

$$
C_{w}(z)=A_{w} \sum_{K} \frac{Q_{K}}{B_{K}} \cdot \frac{L_{K}}{2 \pi R} \delta_{K}(z)
$$

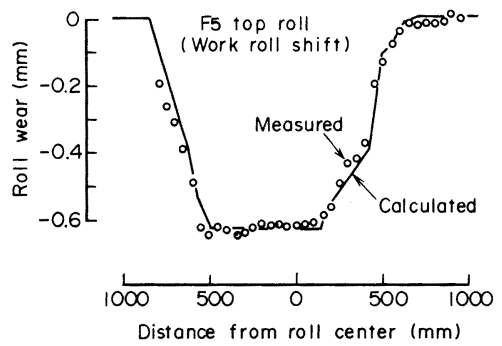

Fig. 4. Comparison between measured and calculated work roll wear profile. 
ここで， $Q$ は压延荷重， $L$ は圧延長さ， $B$ は板幅，添 え字 $K$ は $K$ 番目の圧延材を表す添え字である.

ロール替後のワークロールの摩耗プロフィルの実測值 と計算值の比較を Fig. 4 に示す. 戝はロール摩耗分散 を目的としてロールをシフトしたスタンドの例であるが 実測値と計算值は良く一致している.

$3 \cdot 1 \cdot 3$ VC ロールのふくらみ形状

VCロールのふくらみ形状については，シェル厚一定 な円筒シェルの変形と考え (6)式の解析解によって，ふ くらみ量 $C_{V}(\boldsymbol{z})$ を求める ${ }^{4)}$.

$$
\frac{d^{4}}{d z^{4}} C_{V}(z)+4 \beta^{4} C_{V}(z)=4 \beta^{4} \frac{R_{B}^{2}}{E h_{V}} p_{V}
$$

ここに,

$$
\beta^{4}=\frac{3\left(1-\nu^{2}\right)}{R_{B}^{2} h_{V}^{2}}
$$

$R_{B}$ はバックアップロール半径, $E$ はヤング率, $h_{V}$ は スリーブ厚， $p_{V}$ はVC ロール压力である．Fig. 5 は冷 延レバースミルに導入された VC ロール（ロール径 $1447 \mathrm{~mm}$ ，ロール胴長 $2007 \mathrm{~mm}$ ) のふくらみ量の実測 值と計算值の比較であるが両者はかなり良く一致してい る.

\section{$3 \cdot 2$ 板プロフィル計算モデル}

SHонет $5^{5)}$ の分割モデルをもとに，板プロフィルを オンライン計算できるように繰り返し計算を必要としな い数式モデルを導いた.

板プロフィルを精度良く計算するには，張力応力の幅 方向分布を考慮し，压延荷重の幅方向分布を求める必要 がある. 従来提案されている板プロフィル計算モデル6) では張力応力分布を繰り返し計算するため，計算時間が 長くなりオンライン計算には適用できない。このため, オンライン制御には板クラウン（板幅中央部と端部の板 厚差）のみに着目した簡略式7)が用いられているが，こ

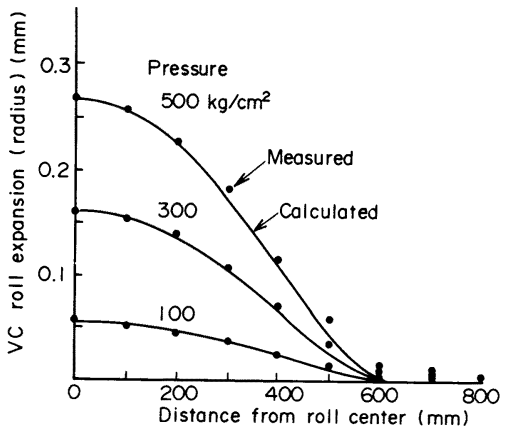

Fig. 5. Relation between roll profile and internal pressure.
れではロールの摩耗や熱膨張などによる板プロフィルの 複難な変化を表すことができない.

筆者らの方法は圧延荷重の幅方向分布を影響係数を用 いて入出口厚分布・前後方張力応力分布の 1 次式で表す ことにより，張力応力分布の影響をも含めた連立 1 次方 程式を導き, 繰り返し計算することなく出口板厚分布・ 圧延荷重分布を求めるものである.

$3 \cdot 2 \cdot 1$ ロール変形モデル

ワークロールシフトミルを対象とするので，ロール間 接触荷重はロールバレル中心に関して左右対称ではない が, 接触荷重の上下平均値

$$
p=\left(p^{U}+p^{D}\right) / 2
$$

に着目すれば左右対象となる。そこで，ロールバレル中 心から片側 $1 / 2$ を細分割し压延荷重・ロール間接触荷 重のロール軸方向の分布を各分割区間内では一様とみな し，ロールバレル中心より $i$ 番目の分割区間における ロール間の単位幅接触荷重を $p(i)$, 压延材からワーク ロールにかかる単位幅压延荷重を $q(i)$, 出口板厚を $h(i)$, 分割区間幅を $\Delta z_{i}$ とするとき，つぎの $(9),(10)$ 式が成り立つ。

ワークロールとバックアップロールの接触部の変位の 適合条件

$$
\begin{aligned}
& -\sum_{j} p(j)\left\{\alpha_{B}(i, j)+\alpha_{w}(i, j)\left\{\Delta z_{j}\right.\right. \\
& -\frac{1}{K} p(i)+\sum_{j} q(j) \alpha_{w}(i, j) \Delta z_{j}+K_{w}-\frac{1}{2} S \\
& =\frac{1}{M_{H}} \cdot \frac{Q+J}{2}-\frac{1}{2}\left(R_{C W}(i)+R_{C B}(i)\right) \\
& \text { ワークロールと圧延材の接触部の変位の適合条件 } \\
& \frac{h(i)}{2}=-\sum_{j} p(j) \alpha_{w}(i, j) \Delta z_{j} \\
& +\sum_{j} q(i)\left\{\alpha_{w}(i, j) \Delta z_{j}+a_{f}(i, j)\right\} \\
& +K_{w}-\frac{1}{2} R_{c w}(i)
\end{aligned}
$$

ここで，Jはワークロールベンドカ， $K_{W}$ はワークロー ル剛体変位, $M_{H}$ は八ウジング・压下系の剛性係数, $S$ は圧下位置である. $R_{C}(i)$ はロールのプロフィルであり， 上下ロールの平均値， $\alpha(i, j)$ はロールの軸心变位の影 響係数であり，これも上下ロールの平均值，添え字 $W$, $B$ はそれぞれワークロールとバックアップロールを表 す. $a_{f}(i, j)$ は压延材によるワークロール表面の偏平変 形の影響係数であり，ロールを半無限体とみなした場合 のロール表面変位 ${ }^{8)}$ を，河野ら ${ }^{6)}$ に従いロール半径に等 しい深さの点の変位により補正した。また，Kはロー ル間のばね定数で $1 / K=3.1 \times 10^{-4} \mathrm{~mm} /(\mathrm{kg} / \mathrm{mm})$ とし た6). 


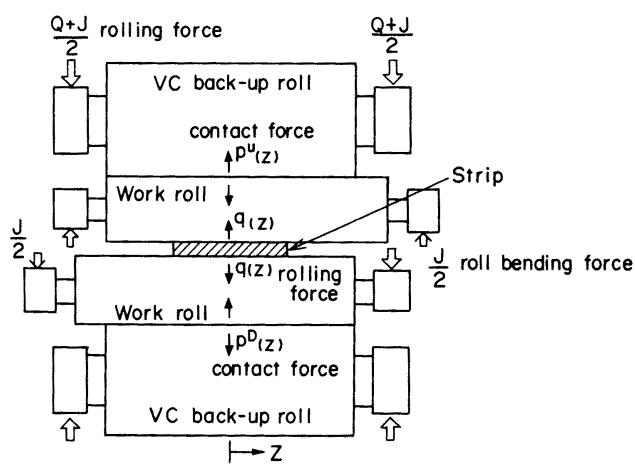

Fig. 6. Elastic deformation of rolls.

\section{$3 \cdot 2 \cdot 2$ 圧延荷重の幅方向分布 ${ }^{9)}$}

単位幅圧延荷重 $q(i)$ を入出口厚 $H(i), h(i)$, 入出口 張力応力 $\sigma_{b}(i), \sigma_{f}(i)$ により(11)式のように表す.

$$
\begin{gathered}
q(i)-q_{c}=\frac{\partial q}{\partial h}\left(h(i)-h_{c}\right)+\frac{\partial q}{\partial H}\left(H(i)-H_{c}\right) \\
+\frac{\partial q}{\partial \sigma_{f}}\left(\sigma_{\jmath}(i)-\sigma_{f c}\right)+\frac{\partial q}{\partial \sigma_{b}}\left(\sigma_{b}(i)-\sigma_{b c}\right)
\end{gathered}
$$

ここで, 添え字 $c$ は板幅中央部の值を表し, 影響係数 $\partial q / \partial h, \partial q / \partial H, \partial q / \partial \sigma_{f}, \partial q / \partial \sigma_{b}$ は SimS の式に張力の補 正を加えたものより導くことができる. ところで, 出口 張力応力分布は伸び歪み偏差 $\Delta \varepsilon_{l}(i)$ ( $\Delta$ は板幅中央部 との差を表す), 板厚方向歪み偏差 $\Delta \varepsilon_{\boldsymbol{h}}(i)$ により (12) 式で表せる。

$$
\begin{aligned}
& \sigma_{f}(i)-\sigma_{f c}=-E_{\rho} \Delta \varepsilon_{l}(i) \\
& \quad=-E_{\rho} \eta(i)\left\{\Delta \varepsilon_{l}^{(-)}(i)-\Delta \varepsilon_{h}(i)\right\}
\end{aligned}
$$

ここで, $E_{p}$ は圧延材のヤング率, $\Delta \varepsilon_{l}{ }^{(-)}(i)$ は入口での 伸び歪み偏差, $\eta$ は粟津原ら ${ }^{10)}$ が提案した塑性流れ係 数であり, 伸び歪み偏差 $\Delta \varepsilon_{l}$ と板厚歪み偏差 $\Delta \varepsilon_{h}$ の比 $\eta=-\Delta \varepsilon_{l} / \Delta \varepsilon_{h}$ として定義される. また, 松本ら ${ }^{11)}$ に従 つて, 入出口張力応力分布は等しいとし, さらに $\Delta \varepsilon_{h}$ について,

$$
\Delta \varepsilon_{h}(i)=\ln \left(\frac{h(i)}{H(i)}\right)-\ln \left(\frac{h_{c}}{H_{c}}\right) \fallingdotseq \frac{H(i)}{H_{c}}-\frac{H(i)}{H_{c}}
$$

とするとき，(10)〜 (13)式よりワークロールと圧延材の 接触部の変位の適合条件(14)式を得る.

$$
\begin{aligned}
& -\sum_{j} p(j) \alpha_{w}(i, j) \Delta z_{j}+\sum_{j} q(j)\left\{\alpha_{w}(i, j) \Delta z_{j}+a_{f}(i, j)\right\} \\
& -\frac{1}{2} \cdot\{q(i)-q(1)\} /\left\{\frac{\partial q}{\partial h}+\frac{1}{h_{c}}\left(\frac{\partial q}{\partial \sigma_{f}}+\frac{\partial q}{\partial \sigma_{b}}\right) E_{p} \eta(i)\right\} \\
& +K_{w}=\frac{1}{2}\left[R_{c w}(i)+\left\{\frac{\partial q}{\partial h} \cdot h_{c}-\frac{\partial q}{\partial H}\left(H(i)-H_{c}\right)\right.\right.
\end{aligned}
$$

$$
\begin{aligned}
& \left.+\left(\frac{\partial q}{\partial \sigma_{f}}+\frac{\partial q}{\partial \sigma_{b}}\right) E_{p} \eta(i)\left(\frac{H(i)}{H_{c}}+\Delta \varepsilon_{l}^{(-)}(i)\right)\right\} \\
& \left./\left\{\frac{\partial q}{\partial h}+\frac{1}{h_{c}}\left(\frac{\partial q}{\theta \sigma_{f}}+\frac{\partial q}{\partial \sigma_{b}}\right) E_{p} \eta(i)\right\}\right] \quad \ldots \ldots . .
\end{aligned}
$$

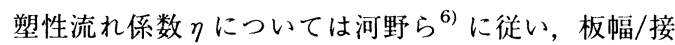
触弧長 $\left(B / l_{d}\right)$ をパラメーターとして計算板プロフィル が実績プロフィルに一致するように調整したが, Fig. 7 に示すごとく従来報告されている数值よりかなり高い数

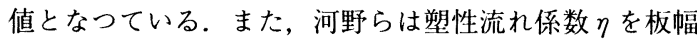
方向に一様な值としているが，ここでは板幅端部におけ る圧延材の变形挙動を表すため板幅端部で減少する分布 を持たせた.アルミ板（幅 $1000 \mathrm{~mm} \times$ 厚 $5 \mathrm{~mm}$ )を実機 ミルにて圧延して, 伸び歪み偏差 $\Delta \varepsilon_{l}$ と厚み歪み偏差 $\Delta \varepsilon_{h}$ を測定することにより塑性流れ係数 $\eta$ の幅方向分布 を求めたものを Fig. 8 に示すが, 板幅端部約 $100 \mathrm{~mm}$ の範囲において減少していることがわかる．塑性流れ係 数の板幅端部での変化と接触弧長・板厚・板幅などとの

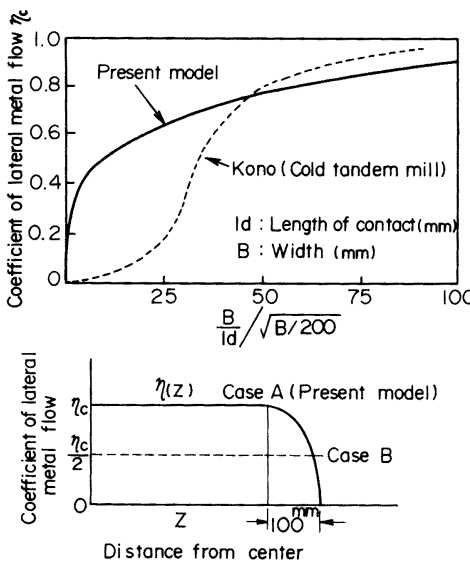

Fig. 7. Coefficient of lateral metal flow.

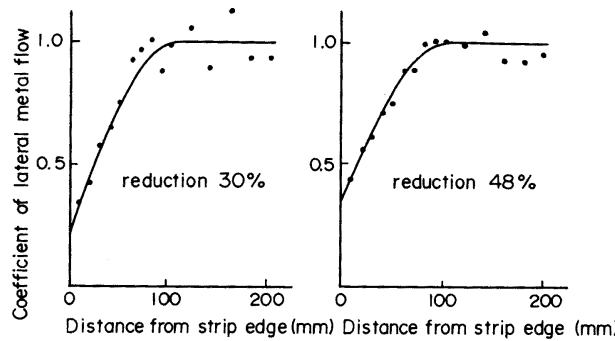

Thickness $5.0 \mathrm{~mm}$ Width $1000 \mathrm{~mm}$

Aluminum Roll diameter $710 \mathrm{~mm}$

Fig. 8. Coefficient of lateral metal flow (experimental result). 
関係，幅拡がりとの関係など 3 次元の変形挙動解析は今 後の研究課題である.

\section{$3 \cdot 2 \cdot 3$ 板プロフィルの計算方法}

適合条件 $(9)$, (14)式と力の釣り合い条件式

$$
\begin{aligned}
& \sum_{j} p(j) \Delta z_{j}=(Q+J) / 2 \\
& \sum_{j} q(j) \Delta z_{j}=Q / 2 \quad \cdots \cdots . .
\end{aligned}
$$

を連立させて, 未知数 $p(i), q(i), K_{W}, S$ について解く ことにより出口板厚分布 $h(i)$ を計算できる. 上記計算 法によつて, 上流スタンドから順次出口板厚分布を計算 していく.

本計算手法をオンラインに適用するに際し，板幅方向 の分割については，板幅中心から片側 $1 / 2$ の材料との 接触部には等間隔に 13 点, 材料と非接触のロール部に は 1 点の分割点を取つた。この場合，演算処理能力約 1 MIPS (1sに 100 万回の命令を実行) のオンライン用 プロセスコンピューターにて，7スタンド分の板プロ フィル計算を約 $4.5 \mathrm{~s}$ で実行できる. Fig. 9 は河野らの 張力応力分布を繰り返し計算により求める手法による板 プロフィル計算結果（ロールバレル片側を 20 分割）と

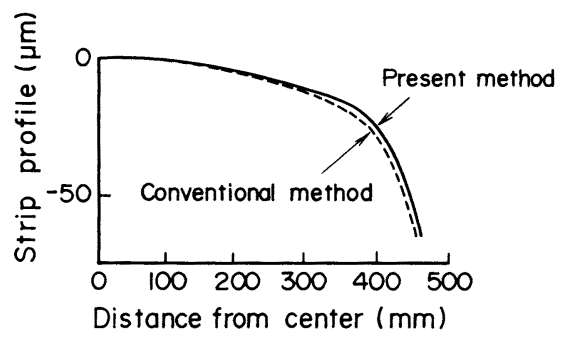

Fig. 9. Comparison of profile calculation method $(952 \times 3.5 \mathrm{~mm})$.
本方法による計算結果との比較を示すが, 両者はほぼ完 全に一致している.なお，この場合の計算時間は本方法 により約 $1 / 100$ に短縮できた。

$3 \cdot 2 \cdot 4$ 板プロフィル計算モデルの精度

$\mathrm{F}_{5 \sim 7} 3$ スタンドの VC ロール压力・ロールベンド力 を変化させた場合の板プロフィル・板クラウン（エッジ $25 \mathrm{~mm}$ ）の測定值と計算值の比較を Fig. 10 に示すが, 両者はよく一致しており計算モデルの精度が良好である ことを示している. Fig. 10 の(1)と(4)の压延条件におい て，塑性流れ係数 $\eta$ Fig. 7 の Case A, Case B 及び Case C $(\eta=0)$, Case D $(\eta=1)$ とした場合の板プロフィ ルの計算結果と測定值との比較を Fig. 11 に示すが, Case A（本方式）が測定值と最もよく一致している. さらに，Fig. 12 には板プロフィル制御をしない压延 チャンスにおける板クラウン変化を計算值とともに示す が $\pm 20 \mu \mathrm{m}$ の精度で計算値と測定值は一致している.

\section{$3 \cdot 3 \mathrm{VC}$ ロール・ロールベンダーの設定計算}

$\mathrm{VC}$ ロール圧力・ロールベンド力の設定計算のフロー チャートを Fig. 13 を示す。まず初期設定条件に対する 板クラウン予測值 $c_{R}{ }^{0}$ を求めるとともに, 該予測近傍 における出口板クラウンへの影響係数 $\alpha_{P}, \alpha_{B}, \alpha_{V}, \alpha_{H}$ を (9)，（14），(15)，(16)式より求める.このとき，出口 板クラウン $c_{R}$ は $(17)$ 式で表せる.

$$
c_{R}=c_{R}^{0}+\alpha_{P} \Delta Q+\alpha_{B} \Delta J+\alpha_{V} \Delta p_{V}+\alpha_{H} \Delta C_{R} \cdots \text { (17) }
$$

ここで, $C_{R}$ は入口板クラウン, 記号 $\Delta$ は初期設定值 からの変化量を表す.

つぎに，板クラウン予測值 $c_{R}{ }^{0}$ 近傍における板クラ ウン推定簡略式(17)をもとに，板クラウン狙い值を実現 し, かつ, 平坦度が許容範用に入るような VC ロール 圧力・ロールベンド力を下流側スタンドから順次決定し

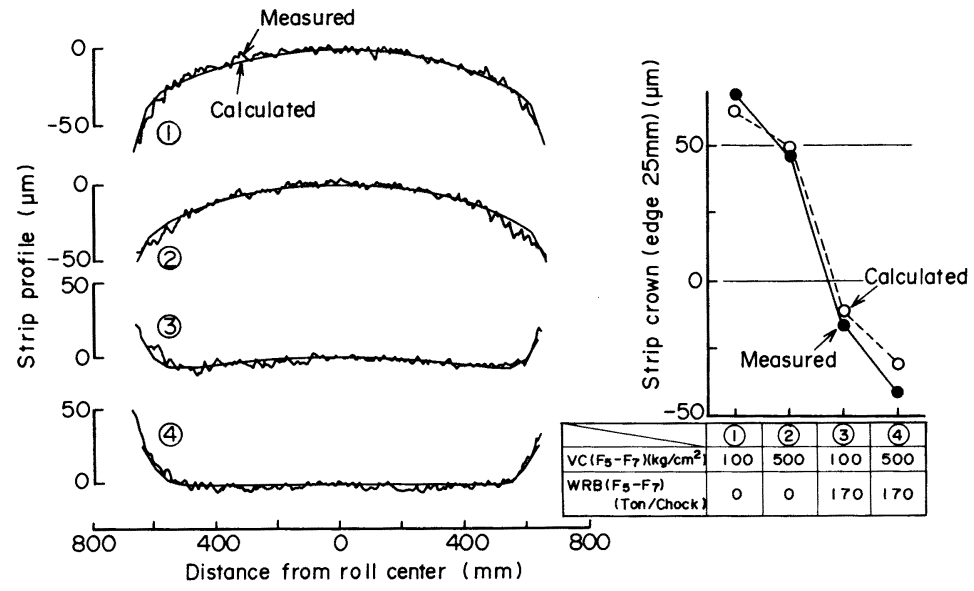

Fig. 10. Comparison between measured and calculated strip profile $(1365 \times 4.2 \mathrm{~mm})$. 

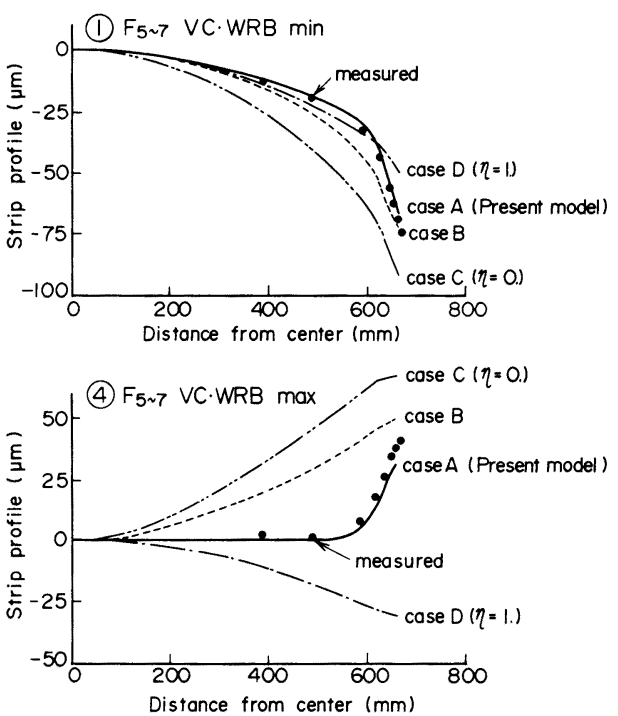

Fig. 11. Comparison between measured and calculated strip profile $(1365 \times 4.2 \mathrm{~mm})$.
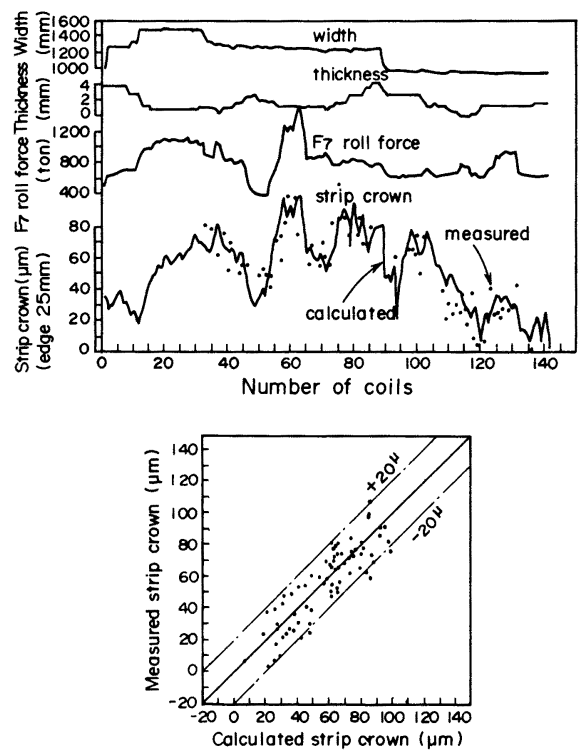

Fig. 12. Comparison between strip crown (edge $25 \mathrm{~mm}$ ) measured and calculated (strip crown control off).

ていくここで, VCロール圧力とロールベンド力は同 じ比率で変化させ平坦条件としては板クラウン比率の変 化を

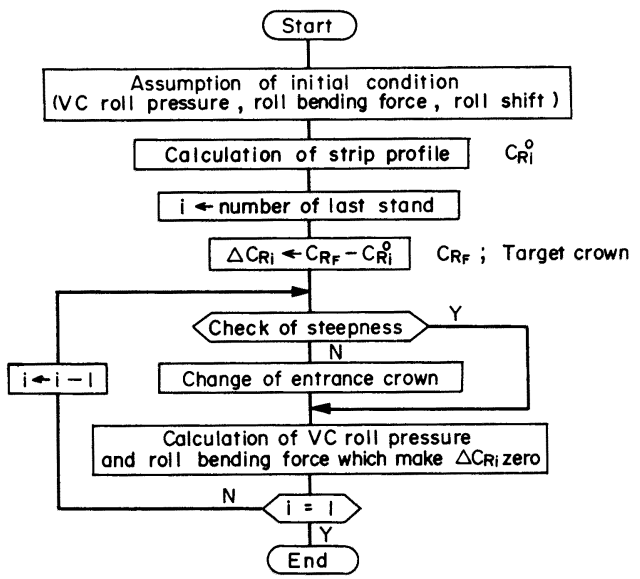

Fig. 13. Flow diagram of crown set up calculation.

$$
-\left(\frac{\pi}{2} \lambda_{\max }\right)^{2} \leqq \eta\left(\frac{C_{R}}{h_{c}}-\frac{C_{R}}{H_{C}}\right) \leqq\left(\frac{\pi}{2} \lambda_{\max }\right)^{2}
$$

にて制約した。なお，急峻度許容值 $\lambda_{\max }$ については実 機にて目視観察して限界を求め $2.5 \%$ とした。

\section{$3 \cdot 4$ 制御結果}

制御結果の一例を Fig. 14 に示す. 図には板クラウン 狙い值を $60 \mu \mathrm{m}$ と $30 \mu \mathrm{m}$ とした場合の VC ロール圧 力, ロールベンド力, 板プロフィルを示すが, 狙いクラ ウンに制御されていることがわかる. Fig. 15 は板クラ ウン狙い值を一定とした圧延チャンスにおける制御結果 であり，Fig. 16 には板クラウン狙い值に対する板クラ ウン実績値の関係を示すが $\pm 20 \mu \mathrm{m}$ 以内の偏差に制御 されていることがわかる.

\section{4. 平坦 度 制 御}

平坦度制御は平坦度計出力信号を比例積分して VC ロール圧力・ロールベンド力を操作するが, このとき板 厚に影響を与えないように(19)式にもとづいて圧下も同 時に操作する.

$$
\begin{aligned}
& \Delta h=\Delta S+\frac{\Delta P_{L C}-\Delta P_{B}}{M}+\frac{\Delta P_{B}}{M_{B}}-\beta_{B} K_{V} \Delta p_{V} \\
& -\beta_{W} \Delta C_{H}
\end{aligned}
$$

ここで, 記号 $\Delta$ はコイル先端部の基準值からの偏差を 表しており， $P_{L C}$ はロードセル検出荷重, $P_{B}$ はロール ベンド力, $C_{H}$ はワークロールのサーマルクラウン,$M$ は圧延荷重に対する剛性係数， $M_{B}$ はロールベンド力に 対する剛性係数， $\beta_{W}, \beta_{B}$ はそれぞれワークロール，バッ 

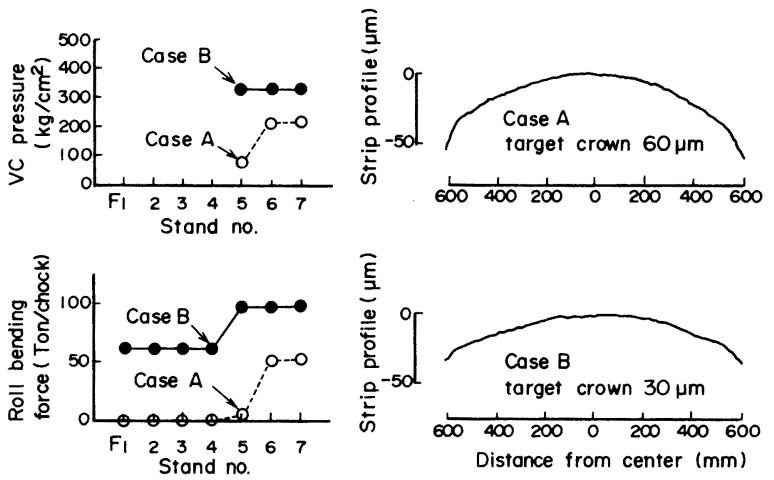

Fig. 14. Examples of strip profile control $(1250 \times 2.3 \mathrm{~mm})$.

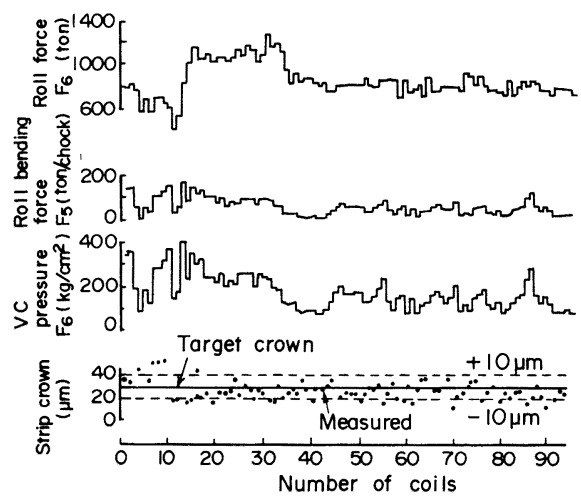

Fig. 15. Example of strip crown variation within one roll change.

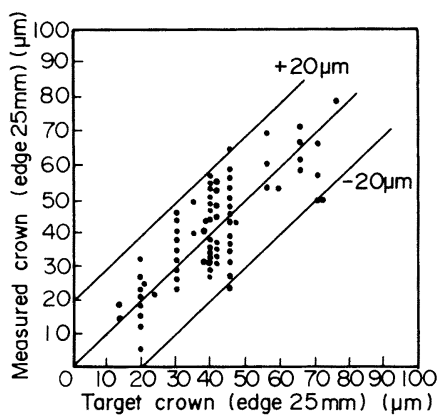

Fig. 16. Result of crown control.

クアップロールクラウンのロールギャップに与える影響 係数， $K_{V}$ はV VCロール圧力によるバックアップロール クラウンの変化率である.

制御実施例を Fig. 17 に示すが，コイル先端で発生し た平坦不良は速やかに修正されている.

\section{5. スケジュールフリー圧延}

鹿島製鉄所では省エネルギーを目的として, No. 3 CC とホットストリップミルを直結化し，高温スラブを 直接熱片専用加熱炉に装入する操業形態となつている. この際，両者の生産能力差を補うため, No. 3 CC スラ ブと他の CC で鋳込まれたスラブを混合して压延する ことになる。これを円滑に実施し，さらに注文の小ロッ ト短納期化に対応するため，スケジュールフリー圧延が 重要な技術課題となる．これへの対応として板プロフィ ル・平坦度制御システムを開発し，スケジュール制約を 緩和することが可能となつた。

Fig. 18 に示す例では，板厚・板幅の移行制約，同一 幅連続圧延本数制約を大幅に緩和しても，板クラウンは 狙い値 $\pm 20 \mu \mathrm{m}$ 以内に制御できている. 図には同一幅 連続圧延時とロール替直前の板プロフィルを示すが，八 イスポット（異常突起）のない良好なプロフィルとなつ ている. なお，この時ロール摩耗を分散させるために 1 コイル圧延ごとに $50 \mathrm{~mm}$ ずつワークロールをシフトさ せた。

\section{6. 結言}

ホットストリップミルの板プロフィル・平坦度制御法 を開発し，住友金属工業和歌山製鉄所・鹿島製鉄所の計 算機制御システムに適用した。

本制御システムは仕上ミル後段 3 スタンドに設置され た VCロール・強力ワークロールベンダー・ワーク ロールシフト装置と, 仕上ミル出口に設置された板プロ フィル計・平坦度計及びこれらを制御するプロセスコン ピューターからなる.

本システムの機能はつぎのとおり。

(1) 狙い板クラウンにするための VC ロール圧力・ ロールベンドカを決定するプリセット制御 

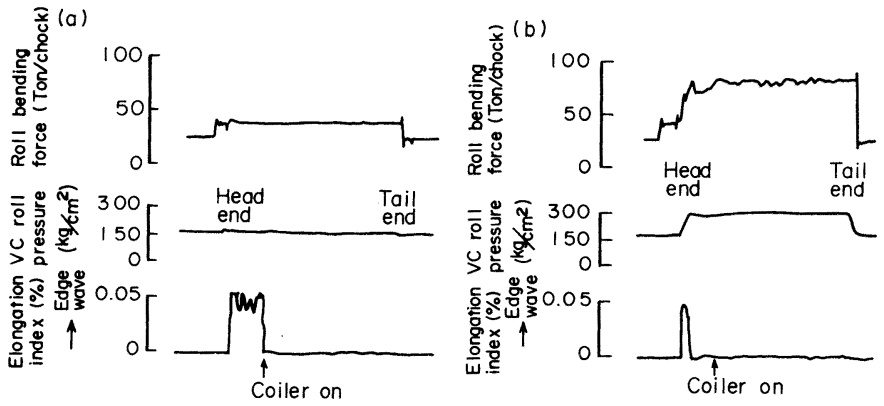

(a) Without shape control

(b) With shape control

Size : $1259 \mathrm{~mm} \times 2.50 \mathrm{~mm}$

Fig. 17. Example of automatic shape control.

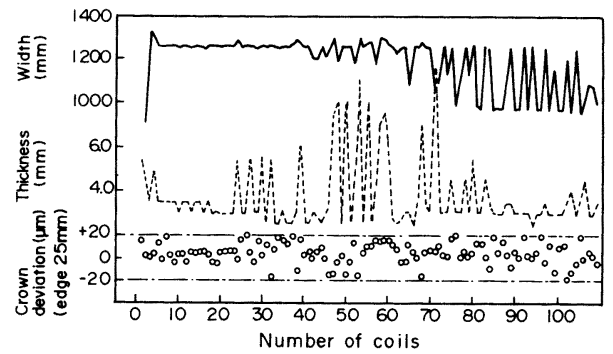

（2）ロール摩耗・サーマルクラウンを分散させるため のワークロールシフト量を決定するプリセット制御

(3) 压延中の平坦度計出力信号にもとづいて VC ロール圧力・ロールベンド力を操作するダイナミック制 御

上記の機能を実現するため，ロールのサーマルクラウ ン・摩耗クラウン・VCロールのふくらみ及び板プロ フィルをオンライン計算できる数式モデルを導いた。

本システムの実用化により板クラウン精度向上，圧延 制約緩和に大きな成果をあげ，品質向上，省エネルギー に寄与している.

\section{文献}

1 ）益居 健, 山田純造, 長井俊彦, 西野隆夫: 塑性と加工,

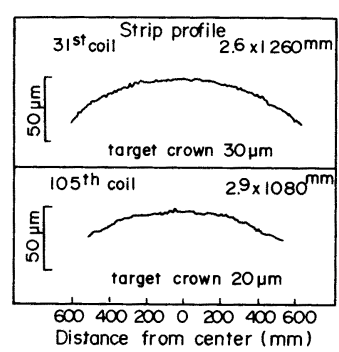

Fig. 18. Example of strip crown control within schedule free rolling.
23 (1982), p. 1188

2 ) 松井健一, 橘 秀文: 鉄と鋼, 72 (1986), S 399

3 ) 有村 透, 岡戸 克, 藤田文夫: 塑性と加工, 16 (1975), p. 44

4 ） P. B. J. Gravina: 回転シェルの理論と計算（1966）, p. 174 [宇野書店]

5 ) $K . N$. Shoнet and $N$. A. TownSEnd: J. Iron Steel Inst. (1968), p. 1088

6 ) 河野輝雄, 美坂佳助: 鉄と鋼, 67 (1981), p. 286

7 ）板圧延の理論と実際（日本鉄鋼協会編）(1984), p. 101

8 ) 戸澤康壽, 上田雅信: 塑性と加工, 11 (1970), p. 29

9 ) 高橋亮一, 美坂佳助, 布川 剛, 八木英剛, 佐藤啓弘: 鉄と鋼，69（1983），S 355

10）粟津原博, 安田健一, 志田 茂, 梶原利幸: 昭和 52 年度 塑性加工春季講演会 (1977), p. 25

11) 松本紘美, 中島浩衛, 菊間敏夫, 上堀雄司: 塑性と加工, 23 (1982), p. 1201 